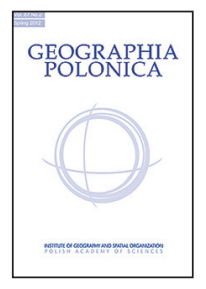

\title{
THE LANDSCAPE OF ABANDONED VILLAGES IN THE WESTERN BIESZCZADY: THE PROBLEM OF DEFINITION AND CLASSIFICATION
}

\author{
Jacek Wolski \\ Institute of Geography and Spatial Organization \\ Polish Academy of Sciences \\ Twarda 51/55, 00-818 Warsaw: Poland \\ e-mail: j.wolski@twarda.pan.pl
}

\begin{abstract}
The Western Bieszczady mountains are an example of a region of Poland whose population suffered extremely heavily from the effects of wartime and post-war migrations linked to political repression. In 1944-1947 and later in 1951, from more than 100 villages in the region that had existed since the 15th and 16th centuries, approximately $90 \%$ of the total number of inhabitants were forcibly relocated - chiefly ethnic Ruthenians (Boykos). The scale in time and space, and the consequences for the landscape, of the natural and socioeconomic processes taking place there over the next 70 years have proved remarkable on even a European scale. The diversity of the former human activity, followed by a combination of abiotic and biotic renaturalisation processes and secondary human pressure, has led to the creation of unique spatial units. The main aim of this article is to address problems relating to the definition and classification of the contemporary landscape of the areas permanently abandoned by human populations in the Western Bieszczady, through the lens of selected conceptual perspectives of other researchers. Deliberations also covered the memory of the subject landscape in the material and information layers (structural and functional continuum, sustainability of spatial units, time in the sense of the historical evolution of landscapes).
\end{abstract}

\section{Key words}

abandoned rural areas - definition and classification of the landscapes - memory of the landscape - Western Bieszczady mountains • Boykos

\section{Introduction}

The abandonment of rural areas by human populations, particularly in mountain regions, is a phenomenon found in virtually all parts of the world. It nevertheless appears in various forms. The first type is change in land use, which is not linked to the drop in population and takes place as a result of disturbances to the internal dynamics of socioeconomic 
systems (Baudry 1991; MacDonald et al. 2000; Gellrich \& Zimmermann 2007). Such a phenomenon is referred to in the European Union's Common Agricultural Policy as 'semi-abandonment' (Land Abandonment... 2005). It most commonly results from the availability of more fertile and easily cultivable land, the opening up of new markets, or the appearance of alternative sources of livelihood and economic development causing rural residents to switch from agriculture to other ways of making a living (Conti \& Fagarazzi 2004). Moreover, most of the areas subject to 'semi-abandonment' are situated outside the regions of greatest economic activity, often close to national borders, where in addition the natural environment limits the development of agriculture (MacDonald et al. 2000; Kozak 2004; Strijker 2005; Kuemmerle et al. 2008). Hence these are regions where almost all negative socioeconomic processes occur with particular intensity (Zagożdżon 1980). A frequent consequence of 'semi-abandonment' is further marginalisation of mountain areas and the disappearance of traditional cultural landscapes. This is confirmed by research carried out, among others, in the Swiss Alps (Gellrich \& Zimmermann 2007), the Mediterranean region (Sluiter \& Jong 2007), and even Himalayan valleys (Khanal \& Watanabe 2006).

The second form of abandonment of rural areas is related to the physical emigration of people due to 'external stress'. The reaction to this may be either slow and indirect, or rapid and direct. In the first case we speak of depopulation, which is a gradual, long-term process, involving migration that is not the result of repression, but is linked to a whole range of natural, socioeconomic and political factors. In Europe there has for many years been a movement of population away from less fertile areas all around the Mediterranean region (Baudry \& Bunce 1991). A classical example of the phenomenon in Poland, on the other hand, was the re-emigration of post-war resettlees in the Sudety Kłodzkie mountain region (Tomaszewski 1968; Salwicka 1978).
In the other scenario, populations leave their home regions as a consequence of administrative decisions, the operations themselves being repressive in nature; they may be (a) compelled by circumstances - the resettlement and relocation of whole villages due to natural disasters (UNHR 2011), industrial disasters (Hostert et al. 2011), major development projects (ForczekBrataniec 2010) or military action (Witmer \& O'Loughlin 2011), or (b) imposed directly - the resettlement of populations out of political and administrative motives (Wolski 2007; Hryciuk et al. 2008).

The most spectacular example in Poland of an area abandoned by its population due to political decisions is the Western Bieszczady mountain region (and also, to a lesser degree, the Beskid Niski region bordering it to the west), situated at the boundary of the Eastern and Western Carpathians in the south-eastern part of the country (Podkarpackie province; Fig. 1). The scale in time and space, and the consequences for the landscape, of the processes taking place there over the 70 years following the displacement of the population have proved to be unparalleled anywhere in Poland ${ }^{1}$ and unique even on a European scale (Wolski 2007, 2009a). The diversity of the former human activity, followed by a combination of abiotic and biotic renaturalisation processes and secondary human pressure (particularly forestry and the activity of large state-owned farms) have led

1 The post-war natural and socioeconomic changes in the Western Bieszczady are often compared to those that took place in the Beskid Niski and Sudety Kłodzkie ranges. Although this approach is justified, it should be remembered that in the first of these regions the objects of material culture (cottages, Orthodox churches, cemeteries) were preserved in much greater number, which meant that some former inhabitants were able to return. In the Bieszczady this happened extremely rarely, and involved only families resettled under Operation "Vistula" (Akcja "Wisła") to Pomerania or Lower Silesia, not those who had been moved to the Ukraine, for whom return was practically impossible. The mountains surrounding the Kłodzko Basin, in turn, represent a typical area of depopulation, from which people moved out over several decades. This means that the phenomena and processes found there are not fully identical to the scenario of the Bieszczady. 
to the creation of unusual types of landscape which are not easy to define unambiguously. What in fact they are rural areas that have been abandoned by their population, where non-material (spiritual) values have disappeared entirely, but where certain historical spatial systems, forms and structures are still visible in the landscape and bear witness to a limited functional and structural continuity, even though the area as a whole can no longer be described as a village landscape (cf. Angelstam et al. 2003)?

The main aim of this article is to address in the light of selected views and perspectives put forward by other researchers - the aforementioned problems relating to the definition and classification of the contemporary rural landscape of the Western Bieszczady, with particular attention to those areas that were permanently abandoned by their population, where in spite of the occurrence of secondary (post-war) human pressure no permanent settlement network has come into being.

\section{The area of study}

The Western Bieszczady mountains occupy the southern part of the historical Sanok Lands and the extreme western edges of the former Przemyśl Lands. In the 15th and 16th centuries, as a result of a major colonisation process initiated in the 14th century by King Kazimierz the Great, and of the migration of Vlachs from southern Europe, this previously uninhabited region came to be settled. For almost 500 years, in more than 100 villages, the Ruthenian population (commonly considered as Ukrainians) farmed and lived peacefully alongside Polish and Jewish minorities. The culture of the Boykos (the name given by pre-war ethnographers to the Ruthenians of the Bieszczady, to distinguish them from other Carpathian ethnic groups - the Lemkos in the west and the Hutsuls in the east) came to an end in the 1940s. Following the Nazi extermination of the whole of the Jewish community of the Bieszczady (1942) and a short period of relative calm, the resettlement of the inhabitants of the western Boyko region ${ }^{2}$ began: firstly to the Ukraine in 1944-1946, and later to various parts of Poland under Operation "Vistula" in 1947 (Moty$\mathrm{ka}$ 1999). An epilogue to this drama took place in 1951, when in connection with the exchange of border territory between Poland and the Soviet Union (Operation "H-T") the inhabitants of another 40 villages in the north-eastern part of the region were forcibly resettled (Klâštorna 2009). Thus repressive migrations affected approximately $90 \%$ of the pre-war population, including all of the Boykos. A region that had teemed with life for half a millennium again came to be almost completely uninhabited (Fig. 1).

The socioeconomic development of the Western Bieszczady (particularly the southern part, known as the High Bieszczady) over the past 170 years can be divided into several distinct stages: crop and livestock farming (from the mid-19th century to 1914/1918), an unstable system of crop and livestock farming with increased emphasis on livestock (from 1918 to 1939/1947), unassisted renaturalisation (1947-1960), secondary human pressure (from 1960 to the end of the 1970s) and assisted renaturalisation (from the start from the 1980s). The stages of unassisted renaturalisation and secondary human pressure were characterised by the most rapid rate of landscape change (subsystems were in a state of disequilibrium or unstable equilibrium), while the pre-war and interwar years and the last quarter-century witnessed much slower change (neutral or relatively stable dynamic equilibrium) (Wolski 2007).

Human activity following 1947 led to the complete elimination or significant transformation of all anthropogenic landscape rudiments (remains of buildings, landforms), thus determining their present-day numbers. Natural factors, being subject to marked local variation, were responsible for their slow evolution and contemporary state of preservation, although their role was relatively small,

\footnotetext{
2 Boykos, like Hutsuls, living in villages in the Eastern Carpathians within the current borders of Ukraine, were not resettled within the described actions in the 1940s.
} 




B

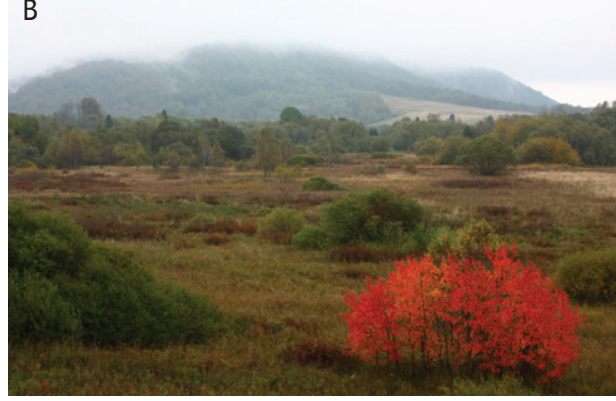

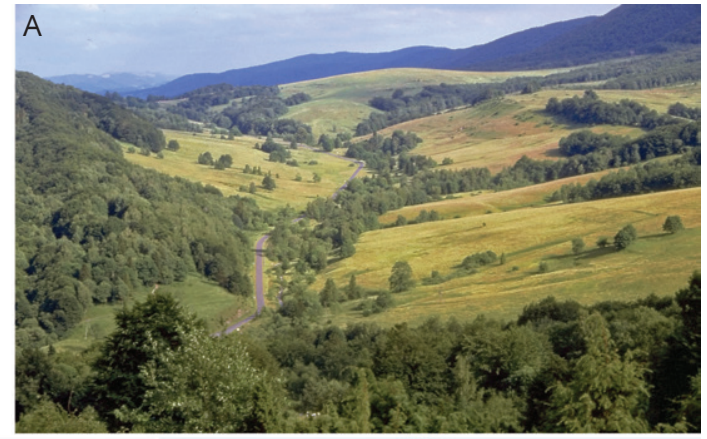

C

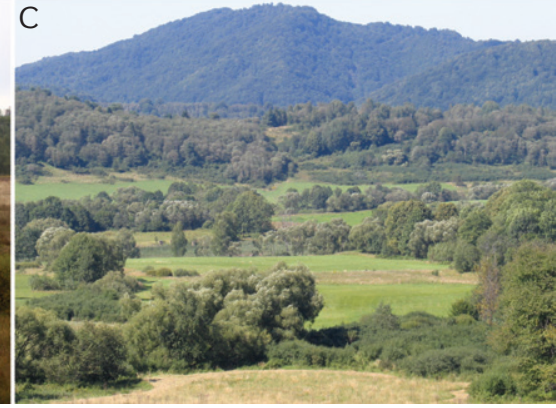

Figure 1. Location of the study area and chosen former village landscapes with population of villages in 1931/2011 (in parentheses): A - Berehy Górne (707/7), B - Wołosate (1084/47), C - Tworylne (863/0) (Photo J. Wolski)

having an impact mainly on structures and forms that were weakly developed or unfavourably situated in the terrain. For example, the greatest losses of scarps of cultivation terraces and infield baulks were recorded in places which after the war were subject to pressure from forestry and grazing, while such losses were least in cases where there was no human activity (evidence of high resilience) or where agricultural use was restored (material up-building) (Wolski 2006, 2008). Another example is provided by the road network, where the dynamics of change from a spatial standpoint varied greatly between time periods (progressive-regressive in the 1960s, progressive-stable in the 1970s, regressive-stable in the last quarter-century) and was conditioned primarily by the development of human settlement and forest management.

The change in the forms and intensity of anthropogenic impact, and in land use and cover, after 1947 also led to the transformation of almost all morphogenetic processes.
As a result of self-seeding of arable land and ravine roads, and of forest succession, some of the changes were stopped (wind erosion, cover runoff, fibrous ice, soil splash), or else their absolute intensity was reduced (surface flow, washing away) or their direction changed (concentrated $\Rightarrow$ dispersed flow, soil degradation $\Rightarrow$ aggradation). This transformation led to changes in types of modelling in all tiers of land use: to the smallest degree in forests (where creep and erosion remained dominant), moderately in mountain pastures (where creep and wash-off gave way to weathering), and to the greatest degree in valleys, particularly in places formerly used as arable fields (where wash-off and wind erosion were replaced by creep). Morphogenetic processes currently exhibit greatest activity on forested slopes, on slopes of valleys used as grassland, and in the channels of streams (Wolski 2007).

In the biotic sphere, in spite of the impact of secondary human pressure, the picture of the landscape today continues to be closely 
linked to the rural picture shaped by the former farming activity and land ownership structure. This is evidenced by, among other things: a) a clear toposequence of actual plant communities (chiefly anthropogenic and seminatural) on the slopes of formerly inhabited valleys; b) the prevalence of postgrazing beeches deformed by animals, fruit trees and trees planted near houses and along former roads; c) traces of former use in the tree stocks of the higher parts of the lowland level (altered species composition and age structure); d) differences in the degree of development of the tree-line and in the type, structure and species composition of the communities forming it; and e) the seminatural origin of the meadow vegetation of the mountain pastures. The changes in flora taking place at present are bringing about a greater uniformity of dynamic status (disappearance of regenerative and pioneer stages) and a decreasing proportion of surface area occupied by seminatural communities, leading to a reduction in numbers of uniform patches (elimination, merger) while their size increases. As a result there is an increase in homogeneity at landscape level, and in heterogeneity (mosaic structure) at regional level, chiefly as a result of increasing differentiation of economically used and abandoned areas (Wolski 2009b).

\section{Landscape - many roads, one goal}

It is hardly possible to discuss specific types of spatial units without first considering landscape in a broad sense. This is without doubt one of the most frequently discussed terms appearing in nearly all subdisciplines of geography and in many related fields; however, the various perspectives on what is de facto the same designatum, in spite of significant complementarity, can scarcely be considered identical (Bastian 2008). The debate on this subject, which has continued unabated for decades, results from the great role played by the term, which almost 100 years ago was described as a "fundamental geographical concept" such that the question of whether a given phenomenon appertains to it "decides whether it is part of the subject matter of geography" (Hettner 1918, 1919, cited by Pietrzak 2006). Also currently of significance is the ever increasing dominance of methodological pluralism over monism, which may lead to the observation that there are as many landscapes as there are (sub)disciplines (or even as there are scholars). The need for classification, evaluation, connection (regionalisation) and division (typology) of fragments of material reality and the creation from them of logical constructs or hierarchies undoubtedly facilitates the characterisation of spatial structures, ongoing processes and interdependencies. On the other hand, it almost always provides only a certain approximation, as a coherent spatial system incorporating people, the economy and nature consists of around 90,000 variables linked by several million relations (Kostrowicki 1992). In practice, therefore, it is not possible fully to analyse or quantify this system, particularly under the holistic concept which states that the determining factors in nature are 'wholes' (Greek hólos) that cannot be reduced to sums of their parts.

Depending on discipline, the term landscape is used in various scholarly meanings. For example, the perspectives associated with geosystems (geoecology) and ecosystems (landscape ecology) use definitions that emphasise the links and dependencies between components (structural-dynamic, functional and systemic aspects), but differ in their approach to the hierarchy of components and taxonomy of spatial units (Richling \& Solon 2011). The landscape and humanist schools of geography also stress the structural-dynamic aspect, but more from a historical-genetic (natural-cultural) standpoint (Myga-Piątek 2012). Landscape architecture, in turn, typically perceives its subject in a manner that emphasises physical appearance or aesthetics (Bogdanowski 1998), similarly to other fields which lie entirely outside geography (sociology, psychology, ethnology, philosophy of nature). 
A survey of the numerous viewpoints and concepts based on globally accepted methodological foundations gives grounds to state that the great majority of definitions are of clearly dichotomous character - natural or anthropocentric (Wojciechowski 1986; Myga-Piątek 2001, 2012; Ostaszewska 2002; Richling \& Solon 2011). Relatively few emphasise the co-existence and interactive links and dependencies of all three landscape systems - biotic, abiotic and anthropogenic (understood to mean cultural) - in accordance with the contemporary concept of the multi-aspectual nature of the landscape, which requires it to be treated to an equal degree as, among others: (a) a collection of physical objects, their aggregations, configurations and subsystems; (b) a system of related processes integrating different physical objects; (c) a set of real and potential services for different groups of users; and (d) a set of spatially connected objects with defined visual appearance and aesthetic values (Solon 2008).

The situation is similar as regards the systematisation of landscape. Under the European Landscape Character Assessment Initiative (ELCAI) more than 50 examples of classifications and typologies of landscapes, from 14 countries, have been studied. Analysis of the criteria has shown that it is natural features that are by far the most commonly considered, followed by socioeconomic and technical features (material culture), whereas cultural and aesthetic features, representing non-material aspects, often including spiritual ones, are taken into account only sporadically (Majchrowska 2008).

\section{Former village landscape}

We now reach the key problem - how to name (define) the rural landscape which is the subject of consideration, and whether it can be placed within existing classifications. In view of the specific nature of the described spatial units, they should not be described with the uncritical use of pre-existing systems of groups of elements or diagnostic features, even if they are fully measurable - neither those which are less or more universal (cf. Plit 2002), nor those which result from empirical studies in other regions which consider, among other things, the presence, numbers and relative proportion (degree of saturation) of selected cultural and natural elements in the landscape (cf. Paprzycka 2005; Bernat 2006).

In studies of the material objects occurring in the real environment, another trap may be the replacement of empirical judgements with solely subjective and a priori evaluations. The image of the environment thus formed in the human mind (the evaluator) is not, after all, an independent objective entity, but is merely a kind of mental construct. Another point is that a certain amount of subjectivism is an intrinsic feature of every judgement, even the most formalised, based on unambiguous criteria and measurable features. It is never possible to achieve the goal of complete independence of the subject of observation from the observer, since there always exists between them some kind of cultural filter (Plit 2011). From a sociological standpoint one may speak of an emotionally marked private personal space, which together with the geographical dimension and the historical context co-creates an image of the landscape - particularly of that which is an element of a person's private (and not ideological) homeland (Połomski 2010).

\section{An attempt at classification}

Before presenting the concepts used in the literature which best reflect the specific nature of the landscapes of the abandoned villages of the Boykos, let us return to the question of their place in existing typologies. The traditional method of evaluation, that with the longest pedigree, based on genetic and visible features, may serve only to characterise whole groups of landscapes (such as rural mountain landscapes). An interesting proposal for a typology using a genetic criterion, resulting from the development and system of cultures and based on prior determination of the chronology of particular elements 
and separation of historical from contemporary forms, was put forward by Dobrowolska (1948). She distinguished the following types of landscapes: the culturally uniform, those with an evolutionary system of cultures, the revolutionarily transformed, those with cultures imposed directly on a geographic substrate, those with cultures imposed on a substrate of former cultures, and those with petrified cultures. In recent years Dobrowolska's typology has been extended by Myga-Piatek (2012: 24), who proposed the concept of stratigraphy of landscape, understood as a system of cultural layers "being reflected by the co-occurrence of landscape elements of different ages, as well as features of spatial organisation typical of different historical periods." This original model of the stratigraphy of cultural landscapes is linked to genetic and evolutionary-functional typologies, but is intended for use in analyses under a regional approach. Many possibilities are also provided by a visual-perceptive typology, which takes account of both the variability in the physical appearance of landscapes and people's multisensory perception of them (Myga-Piatek 2012). From this standpoint, the permanently abandoned Boyko villages may currently be classed as evolutionarily variable landscapes, although at the time of the resettlements they would have been classifiable as revolutionarily variable (disappearing), since they were subject to irreversible processes leading to the permanent loss of many quantitative and qualitative features.

In functional-structural classifications, in which the distinguishing criteria include, for example, the chief types of human economic activity or groups of selected and well-recognised elements or processes, rural areas are treated as: (a) functioning spatial systems, consisting of natural and socioeconomic elements (the geographical perspective); (b) assemblies of spatially and functionally connected ecosystems of agricultural, seminatural, natural and fallow lands (the ecological perspective); or (c) particular forms of filling of space, described by relations between the productive and non-productive spheres and by a specific type of human activity (Cymerman et al. 1992). Physical geography thus concentrate chiefly on the degree of anthropogenic transformation of the environment and biophysical characteristics of landscape, while in socioeconomic geography priority is given to social and ownership features (ownership structure and sizes of individual farms, density of agricultural population), organisational and technical features (organisation of land layout, use structure, nature of buildings, way of use) and productive features (types of crop and animal production).

The abandoned areas within the western part of the region historically settled by the Boykos are also not easy to classify under the typologies of settlement geography. The interesting concept of 'vanishing villages' in the Sudety Mountains (Chachaj 1978) is terminologically adequate only superficially. The main factor behind that process is a specific form of urbanisation, which involves not the transformation of buildings or the spatial system, but changes in the mentality of inhabitants (switching to non-agricultural ways of making a living, reduction in the level of agricultural culture, change of lifestyle and widespread intent to emigrate to towns), and consequently in the function of the locality. In a certain sense the 'vanishing village' can be considered an archetype of the phenomenon of 'semi-abandonment' described at the beginning of this article.

The foregoing examples show that most of the diagnostic features used in the described typologies relate primarily to villages that currently exist, where there occur living relations between the productive and non-productive spheres, and specific types of human activity. In the case of the region under discussion, that ordered world of meanings has been changed into an unordered space governed primarily by the laws of nature.

Greater differences can be found in the typologies used in landscape architecture, historical geography and anthropogeography. Units are distinguished in terms of the shape and coverage of the terrain and 
historical features, while to particular categories are assigned successive stages - from the most typical forms to those of a rudimentary nature (Jabłoński 1998).

\section{An attempt at definition}

Another fundamental problem is the term itself and the definition of subject landscape. Here the terminology of physical geography, or more broadly the Earth sciences in their physical geographic aspects, is modest. It would undoubtedly be convenient to name the landscape of the Boykos' villages abandoned almost 70 years ago simply as a seminatural landscape (as defined by Bakker 1979), or as a quasi-cultural landscape, which Myga-Piątek (2012) defines as an evolutionary stage between natural and cultural landscapes, or as a state of preservation characterising the contemporary functional type of protected cultural landscapes. The semantic capacity of this term is too large, however, for it to be successfully used to convey even approximately the specific character of the subject of our considerations. In any case, the classification of landscapes in terms of degree of naturalness, into primary, natural, seminatural and anthropogenic (including in a cultural sense) now generally appears somewhat insufficient, particularly in the light of the new conceptual considerations and increasingly exact empirical studies of the end of the 20th century and the beginning of the 21st.

Much greater possibilities for the application of existing terms are provided by the legally sanctioned concept of cultural landscape - enjoying a spectacular renaissance in recent years - defined as "space as perceived by people, containing natural elements and products of civilisation, shaped historically by the effects of natural factors and human activity" (Dz.U. [Polish Journal of Laws] 2003 no. 162 item 1568 as amended). At present, however, it is increasingly proposed to move away from a rigid separation of actually existing landscapes into natural and cultural, since all of them bearing marks of human influence (Richling 2006). A geographical environment should be treated as a megasystem combining two fundamental categories of space: the system of the natural (physical) environment, and that of the anthropogenic (socioeconomic and cultural) environment. People, in the latter system, constitute both an element of the system (activity within the sociosphere or noosphere) and its creator, the active producer of the culturosphere and technosphere (Degórski 2005). Pietrzak (2006: 115) goes a step further, questioning whether cultural environments in fact exist, and claiming that "de facto all landscapes are cultural landscapes." After all, the adaptation of nature is a part of culture, while a natural landscape may be part of a cultural region, since it is people who have given it significance and value (Orłowska 2005). This means that "nature is not merely nature in the sense of a "timeless and unchanging" divine entity, but is also an entity constructed and transformed by society" (Połomski 2010: 14). As Dobrowolska (1948: 156) long ago observed, "the cultural landscape is a synthesis of the activity of society in its geographical environment. It is what best reflects the interdependence and relationship of the life of nature and human societies, the intensity and speed of changes taking place in the course of long historical development." In a similar tone, Jabłoński (1998: 36) remarks that "a harmonised cultural landscape at local level, with the whole content of historical heritage, is an expression of the spatial order of the local or regional community. Devastation of this order indicates lack of proper management in the economic and social space, a social and cultural egoism in striving to satisfy only short-term aims." Such perspectives are in accordance with the idea of the unity of nature and culture and the ensemble complexe conceived by Vidal de la Blache (1922). In the view of this leading French geographer, landscape in a broad sense is a product of history and culture, which determine ways of living and human relations with nature, while cultural landscape (paysage humanisé) 
reflects how particular groups of people interpret and use their environment. According to Kopczyński (2009: 59) "it is not possible to speak of landscape independent of humanity. Even in the case of a fragment of space untouched by changes in civilisation, the very perception of it is imbued with social content. Emotional reception and aesthetic assessment are inseparably linked to cultural codes." It must not be forgotten, however, that "people are not able to create a landscape, but may only act on the quality of an existing landscape for the purpose of changing it. In effect there is created a landscape of a different quality, which a given actor or other people will be able to experience" (Borkowski 2008: 388). Of course, the discussion may be the fact that, for example, totally artificial postmining landscape is an act of creation completely new or still only change of quality existing landscape.

It can be seen, then, that in spite of their different forms of words and priorities (marginalisation of certain phenomena and magnification of others), scholars are to a fairly large degree in agreement as to the principles relating to the erasure of divisions between natural and cultural landscapes, at least as regards declarations. This is significant in that they include representatives of all of the five main currents in landscape geography, as distinguished and described by Plit (2011): the traditional (classical), the physical geographical, that of the geography of cultural landscapes viewed from real and semiotic (symbolic) perspectives, and the aesthetic standpoint.

Of course, the concept of cultural landscape has too great a generality and semantic capacity (Philips 1998; Wojtanowicz 2002). It requires internal differentiation, which in the case of the still poorly developed typology of cultural landscapes is not a simple task. For confirmation of this we may again turn to Plit (2011: 85), who writes that "study of the diversity (differentiation) of cultural landscapes is perhaps the greatest challenge in contemporary geography, at least in the sphere of explanation - the greatest, most ambitious and most difficult area for scholars to show what they can do."

Let us attempt, however, to present some terms whose meanings, relatively speaking, come closest to describing the areas containing the abandoned Boyko villages. It is symptomatic that most of them are associated with the school described as the geography of cultural landscapes viewed from a real perspective. The first such term, 'landscape of petrified cultures', along with the whole of an interesting typology (Dobrowolska 1948) proved stillborn, since the author failed to define the concepts used or the selection criteria or diagnostic features, thus hindering empirical identification and the reproducibility of observations. Bernat (2006), in a study of the Bug valley, distinguished 'vanished landscapes' (lost, existing in the past, such as the building systems of small towns with markets and characteristic structures) from 'vanishing landscapes', from which certain component elements are contemporarily removed (as in the case of village agricultural landscapes). This classification also includes types of landscapes described as 'new', 'stabilised' (in practice including only protected areas) and 'developing'. In their typology, Vos and Meekes (1999) ${ }^{3}$ use the term 'marginalized vanishing landscape: landscape as a ruin', applying it to rural areas that have been abandoned by people and are subject to processes of secondary succession, which is de facto the closest semantically to the villages being described. Similar terms and expressions are used by other researchers, as best proved by the collection of works titled Landscape Studies and Dying Landscapes (Chylińska \& Łach 2010). Similarity does not, however, imply complete synonymy, and thus does not necessarily permit a term to be appropriated. For example, Kulczyk (2010) divides 'dying landscapes' (both natural

\footnotetext{
3 Vos and Meekes (1999) also distinguished: 'industrial production landscape: landscape as an industry', 'overstressed multifunctional landscapes: landscape as a supermarket', 'archaic traditional landscape: landscape as a historical museum' and 'natural relict landscapes: landscape as a wilderness'.
} 
and cultural) into 'endangered', 'recreated' (reconstructed physically or mentally) and 'vanished'. The greatest value of those of the last type is the material elements serving as evidence of a previous state; that is to say, the described permanently abandoned rural areas may to a certain degree be assigned to this group. They may similarly be assigned to the 'waning landscapes' of Wojciechowski (2010), although this does not result explicitly from the text of his work. In turn Kistowski (2010), using the term 'landscape extermination', presents a very interesting critical view of the seven cardinal sins of Polish society against the landscape. Also popular among planners is the concept of 'relic landscape' (or more correctly: landscape with relic features), characterised by stable function and ossified form, acquiring new values by dint of the contrast with its changing surroundings (cf. Dobrowolski 1970).

A representative of the aesthetic current in landscape geography was Jabłoński (1998), who proposed distinguishing 'landscapes of contemporary and historical ruralist systems' as one of the types of disturbed cultural landscapes. This description is semantically close to the spatial units under consideration, but is also associated with a persistent disharmony, indicating "irreversible processes of loss - disappearance of landscapes (natural and cultural) in both quantitative and qualitative (visual, material, functional, mental, semiotic, etc.) senses" (Myga-Piątek 2012: 10-11). In the case of the villages abandoned by the Boykos, however, one can hardly speak of the total disappearance of the resources in question. An example is given by the valleys of the High Bieszczady, which still exhibit the co-existence of their culture, tradition and canon, since:

- they are areas of self-contained existence (valley ecosystems);

- they are landscape interiors, having a physical surrounding which also constitutes an objective delimitation of their form;

- they have their own culture (for example, roads, agricultural terraces and cemeteries are objects, and the valleys are places, hence these together create the dualism essential for that feature);

- they have their own tradition (they are part of a space with a defined identity);

- they contain certain contexts (natural, landscape, cultural) which contribute to the degree of perception by people;

- they have a specific form (mountain valleys).

Interesting sociological interpretations are given by Schama (1996, cited in Połomski 2010), who distinguishes the 'landscape of the borderlands', which features the coexistence of different, only fragmentarily discernible pasts, and the 'landscape of death' related to the tragic events of the 1940s (extermination of the Jewish population, forced resettlements, the struggle with the Ukrainian Insurgent Army).

Note should also be taken of a typical natural scientific perspective on the matter. The leading geobotanist Faliński (1986, 2001), whose approach was somewhat similar to that of the physical geographers, used the term 'liberated environment' to describe secondary succession on unused, former agricultural land within ecosystems which were formed as a result of permanent human pressure but were subsequently released from that pressure.

In the context of the considerations outlined above, several years ago the author proposed the term 'former village landscape', which he defined nominally as "an area functionally and spatially connected with villages that have been abandoned by their population, characterised by: (a) the vanishing or strong disturbance of an artificially imposed state of equilibrium, as a result of permanent or temporary interruption to or significant reduction in human economic activity; (b) the flow of material, energy and information between the landscape system and society being reduced almost to zero (dying interactions) or destabilised as a result of secondary anthropogenic influences; (c) the dominance of unassisted or human-assisted natural processes, including those being an indirect 
consequence of the interrupted economic activity; (d) the presence of preserved elements of material culture which continue to influence the functioning of the landscape to varying degrees" (Wolski 2007: 15).

This approach requires a brief comment. In the literature one can encounter the apparently similar term 'formerly rural landscape' - in that perspective the main differentiating factor is the primary present-day function of the area in question (Cymerman et al. 1992). In the author's view, however, this term serves to describe areas where the features of village character have been permanently erased, the contemporary picture in terms of the culture, tradition and canon of the place being entirely different. The term 'former village landscape', on the other hand, indicates that certain historical spatial systems, forms and objects still exist and testify to a limited functional and structural continuity, even though the area as a whole can no longer be described as a village landscape.

\section{A landscape with memory or memory of the landscape?}

The factors determining the existence of the former village landscapes as defined above, as material (objective) entities and not exclusively as ordering categories, are the forms and intensity of secondary (post-war) human pressure, affecting the possibility of regeneration of natural spatial units ${ }^{4}$. But does

4 Regeneration is effective when destructive effects lead only to a reduction in the efficiency of processes (degradation), changes in mechanisms of material and energy flow (dysfunction) or changes in structure (decomposition). It becomes impossible or unprofitable (requiring too many supporting operations) in case of comprehensive degradation of the landscape, manifested in the total breakdown of dependencies between components, disappearance of stabilising mechanisms and capacity for self-regulation, and irreversible reduction of biotic potential (Lach 1984; Kostrowicki 1992; Kowalczyk 1997). The rate of regeneration is further conditioned by the different susceptibility of different components of the environment to changes - including both natural and long-term changes, and short-term changes of an oscillatory nature, often associated with various forms of human economic activity. the present material form of a former village landscape entitle us to speak of a clear continuum in the sense of time, space, phenomena and processes, or are we dealing rather with an entirely new entity, being a product on the one hand of nature's tendency to eliminate the effects of human activity, and on the other hand of secondary human pressure?

According to Kienast (1993) the current landscape is only a temporary state in the whole of its historical evolution. Berninger (1975: 37) writes similarly that "the current landscape is a "snapshot" in its variable [...], unfinished development". In the view of Trojan (1980), changes within the smallest typological units do not have a significant effect on the whole internal structure, which may return to its original state after human pressure disappears. By the same token, all transformations of the landscape which do not cause its irreversible degradation are of only a temporary nature, and existing anthropogenic systems may be described as unstable.

A different view is expressed by Dobrowolska (1948: 156, 158), who writes that "society leaves in the landscape in every historical period a picture of its epoch, strictly speaking a picture of its way of adapting to the conditions of its habitat", consisting of "surviving elements and landscape relics with no connection to present-day life." Also Myczkowski (1998) and Myga-Piatek (2005) claim that every landscape has preserved to some degree traces or elements originating from different historical epochs (cultural layering) and being evidence of the historical evolution of the space and of the culture in question. The components of this particular kind of spatial stratification together make up the tradition and culture of the place (factors related to the whole system of historical layers and being currently expressed in the landscape) and its canon, namely the form (picture) of a place with an existing or source-documented form perceived by people. It is thus possible to speak of the landscape's memory - what we see contemporarily is the consequence and heritage of earlier methods of use (Haines-Young 2005, cited in Reger et al. 2007). 
Closely linked to the above considerations is the question of the permanence of the landscape, described by the stability of internal characteristics in conditions of relatively unchanging surroundings and ability to return to the original state following the cessation of external factors (long-lasting disruption or short-term, one-off disturbances). Under this definition, the permanence of a landscape system is characterised by several properties (Farina 2000; Richling \& Solon 2011):

- equifinality - chiefly of mixed type, when following the cessation of disturbances some of the characteristics of the system return to a state identical to the original state, and the remainder to a state close to the initial state; the return of the system as a whole to a state identical to the original state (equifinality sensu stricto) or close to the original state (approximate equifinality) occurs in nature only sporadically if at all, while the preservation of only basic types of relations (equifinality of relations) occurs in much more heavily transformed systems;

- constancy - invariability of the system in a specified time interval;

- elasticity - the time (period of relaxation), manner or degree in which the initial characteristics of the system are recreated following the cessation of disturbances.

High permanence occurs in a situation where the suspension of external influences does not lead within a short time to a return to the initial situation, namely loss of preceding and acquisition of new (original) features. However, as Balon (2006) rightly notes, in reality there is no such thing as complete permanence of the landscape, since dynamics are an inherent feature of stability in nature.

The evidence of the structural and functional continuum visible at present in the material layer is successively erased over time. The process of disappearance is asynchronous, and its rate is different for particular component elements of the landscape. Hence a key factor, without doubt, is time in the sense of the historical evolution of landscapes.
Considering a sufficiently long time horizon (tens or hundreds of years) and a totally natural course of processes of relaxation ${ }^{5}$ one may assume that all direct evidence and indirect consequences of the former human economic activity will be permanently removed from the landscape. It should be taken into consideration, however, that in the most probable scenario of mixed equifinality some characteristics of the system may return to a state that is at most close to, but not identical to, the initial state. Nature will thus tend to erase 'anthropogenic scars', but using new paths of development and creating new qualities which are structurally and functionally much closer to natural than to artificial states, but cannot be fully identified with them. Can we speak in such a situation of the total cleansing of the memory of the landscape? Would the new entities in fact constitute a kind of tabula rasa? This may be the case in the material layer, at least theoretically, but certainly not in the information layer. It is worth making mention here of an interesting model for analysis of the informational, utility, aesthetic, emotional and symbolic value of landscapes (Myga-Piątek 2012). Considering that author's proposed system of criteria, there is a very encouraging prospect for evaluation of the information value of the areas abandoned by the Boykos, consisting of the following features: content (a group of related structural elements of the landscape giving it a defined sense, significance and importance), age (including the presence of datable elements and the permanence of relations and links between them), historicity (the possibility of treating the landscape as evidence of historical events), authenticity (originality, consistency of structure and function), representativeness (degree of preservation

\footnotetext{
5 In practice such an approach excludes any kind of human intervention, including recultivation of land, creation of alternative systems, restitution (restoral of a natural state), rehabilitation and maintenance (improvement and reinforcement with the possibility of transformations, e.g. mowing and extensive grazing with limited stock, having ecological importance) and conservatory protection (unconditional preservation).
} 
of characteristic features), and uniqueness and separateness.

It must be remembered that the elapse of time is not conducive to objective judgement, since the subjects of our recollections may to an increasing degree be subject to mythologisation. Górka (2011: 251) writes that "myths are a past which has been transformed by the imagination and narrated. They are a past that has been remembered and recorded with intent, and hence not necessarily in accord with the facts. [...] Myths come into being when there is a crumbling of the memory of the living about the times to which they relate. They are a metaphor of loss, created «in exile», outside the place of the events which they describe." In this situation the recreation of facts from a historiographic perspective, the chronology of events or causal relations, takes second place to what is de facto the study of memory and its connections with history. Without any doubt, however, the past, in spite of any potential complications in the process of its cognition, is the most important building block in an individual's own identity, since "the certainty that "I was" is an inevitable element of «l am»" (Połomski 2010: 28).

\section{Conclusions}

As was stated at the outset, the aim of this article was to shed light on the numerous problems and ambiguities related to the perception, naming, definition and finally systematisation of the landscapes of abandoned Boyko villages. It is this last problem that appears to be the most difficult, since apart from the dilemmas already described which make it hard or impossible to apply existing classifications, a problem is posed by the imprecise boundaries between categories, whose criteria (features) have also not been sufficiently precisely and clearly defined - or conversely, existing categories are very narrow and serve to describe only specific cases, without the possibility of redefinition and extrapolation to other regions.

Nonetheless, it can be stated without any question that in the case of the described landscapes of abandoned villages in the Western Bieszczady it is not appropriate to speak of nature in isolation from culture or vice versa. The presently occurring former village landscape, as defined in this work, still carries the clear imprint of several centuries of human economic activity. This is easily visible in the form of traces of former roads, agricultural terraces and baulks on the slopes, remains of residential and farm buildings and places of worship, and transformations in the biotic sphere and in soil levels, but there are also some elements that are more hidden, as evidenced by, for instance, the evolution of morphogenetic processes as an indirect consequence of changes in land cover and use. It is here that the material rudiments are imbued with symbolic values, and natural processes have led to a spatial arrangement that is unique on a European scale. Here the landscape which provided a background for history has now become its product (Vincenz 1980), a kind of palimpsest and at the same time the most durable monument to a society (Dubos 1986), carved by that same society according to its needs and abilities for more than five centuries (Wojciechowski 2001).

Editors' note:

Unless otherwise stated, the sources of tables and figures are the authors', on the basis of their own research. 


\section{References}

Angelstam P., Boresjö-Bronge L., Mikusiński G., Sporrong U., Wästfelt A., 2003. Assessing village authenticity with satellite images: a method to identify intact cultural landscapes in Europe. AMBIO: A Journal of the Human Environment, vol. 32, no. 8, pp. 594-604.

BaKker P.A., 1979. Vegetation Science and Nature Conservation [in:] M.J. Werger (ed.), The Study of Vegetation. The Hague: Junk Publishers, pp. 249-288.

BALON J., 2006. Stability of the natural environment as a subject of geoecological research [in:] A. Richling, B. Stojek, M. Strzyż, I. Szumacher, A. Świercz (eds.), Regionalne Studia Ekologiczno-Krajobrazowe. Problemy Ekologii Krajobrazu, vol. 16, no. 1, pp. 101-114.

BASTIAN O., 2008. Landscape classification - between fact and fiction [in:] J. Lechnio, S. Kulczyk, E. Malinowska, I. Szumacher (eds.), Klasyfikacja krajobrazu. Teoria i praktyka. Problemy Ekologii Krajobrazu, vol. 20, pp. 13-20.

BAUDRY J., 1991. Ecological consequences of grazing extensification and land abandonment: role of interactions between environment, society and techniques [in:] J. Baudry, B. Bunce (eds.), Land abandonment and its role in conservation. Options Méditerranéennes, série A, Séminaires Méditerranéens, vol. 15, pp. 13-19.

Baudry J., Bunce B. (eds.), 1991. Land abandonment and its role in conservation. Options Méditerranéennes, série $A$, Séminaires Méditerranéens, vol. 15.

Bernat S., 2006. Dokumentowanie ginacych krajobrazów [in:] P. Gierszewski, M.T. Karasiewicz (eds.), Idee i praktyczny uniwersalizm geografii. Geografia fizyczna. Dokumentacja Geograficzna, vol. 32, pp. 14-19.

Berninger O., 1975. Historia krajobrazu [in:] Z. Obmiński (ed.), Kształtowanie krajobrazu a ochrona przyrody. Warszawa: PWRiL, pp. 37-48.

BogdanOwskI J., 1998. Ochrona krajobrazu kulturowego w ujęciu wnętrz architektoniczno-krajobrazowych (WAK) [in:] Z. Jabłoński, W. Tomaszewski (eds.), Ochrona wartości przyrodniczych i kulturowych - metodyka opracowań studialnych. Przegląd Regionalny, vol. 3, no. 1, pp. 17-31.
BORKOWSKI Z., 2008. Kryteria klasyfikacji krajobrazów [in:] J. Lechnio, S. Kulczyk, E. Malinowska, I. Szumacher (eds.), Klasyfikacja krajobrazu. Teoria i praktyka. Problemy Ekologii Krajobrazu, vol. 20, pp. 385-391.

ChaCHAJ J., 1978. Problem wsi zanikajacej. Acta Universitatis Wratislaviensis, vol. 324, Prace Instytutu Geograficznego, ser. B, no 2, pp. 119-123.

ChYLIŃSKA D., ŁACH J. (eds.), 2010. Studia krajobrazowe a ginace krajobrazy. Wrocław: Instytut Geografii i Rozwoju Regionalnego UWr.

Conti G., FagarazzI L., 2004. Sustainable mountain development and the key-issue of abandonment of marginal rural areas. Rivista PLANUM, vol. 11, pp. 1-20.

Cymerman R., Falkowski J., Hopfer A., 1992. Krajobrazy wiejskie (klasyfikacja i kształtowanie). Olsztyn: Wyd. ART.

DeGÓRSKI M., 2005. Krajobraz jako obiektywna wizualizacja zjawisk i procesów zachodzacych w megasystemie środowiska geograficznego [in:] U. Myga-Piatek (ed.), Krajobraz kulturowy. Aspekty teoretyczne i metodologiczne. Prace Komisji Krajobrazu Kulturowego PTG, vol. 4, pp. 13-25.

DobroWOLSKA M., 1948. Dynamika krajobrazu kulturalnego. Przegląd Geograficzny, vol. 21, no. 3-4, pp. 151-203.

Dobrowolski K., 1970. Studia nad teoriq kultury ludowej. Zagadnienie reliktu kulturowego w świetle materiałów źródłowych z południowej Małopolski [in:] W. Antoniewicz(ed.), Pasterstwo Tatr Polskich i Podhala, 8, Wrocław - Warszawa - Kraków: Zakład Narodowy im. Ossolińskich, pp. 165-210.

Dubos R., 1986. Pochwała różnorodności. Warszawa: Państwowy Instytut Wydawniczy.

FALIŃSKI J.B., 1986. Sukcesja roślinności na nieużytkach porolnych jako przejaw dynamiki ekosystemu wyzwolonego spod długotrwałej presji antropogenicznej. Wiadomości Botaniczne, vol. 30, no. 1, pp. 25-50.

FALIŃSKI J.B., 2001. Przewodnik do długoterminowych badań ekologicznych, ser. Vademecum Geobotanicum, 1, Warszawa: Wydawnictwo Naukowe PWN.

Farina A., 2000. The Cultural Landscape as a Model for the Integration of Ecology and Economics. BioScience, vol. 50, no. 4, pp. 313-320. 
Forczek-Brataniec U., 2010. Zmiany w krajobrazie wokót zbiorników wodnych w Pieninach. Monografie Pienińskie, vol. 2, pp. 259-279.

Gellrich M., Zimmermann N.E., 2007. Investigating the regional-scale pattern of agricultural land abandonment in the Swiss mountains: A spatial statistical modelling approach. Landscape and Urban Planning, vol. 79, pp. 65-76.

GóRKA A., 2011. Krajobraz kulturowy wsi jako nośnik mitu [in:] S. Bernat (ed.), Niematerialne wartości krajobrazów kulturowych. Prace Komisji Krajobrazu Kulturowego, vol. 15, pp. 248-258.

HAINES-YOUNG R., 2005. Landscape pattern: context and process [in:] J.A. Wiens, M. Moss (eds.), Issues and Perspectives in Landscape Ecology. Cambridge: Cambridge University Press, pp. 103-111.

Hettner A., 1918. Die allgemeine Geographie und ihre Stellung im Unterricht. GZ 24, pp. 172-178.

Hettner A., 1919. Die Einheit der Geographie in Wissenschaft und Unterricht. Geogr. Abende im Zentralinst. Berlin: F. Erziehung und Unterricht, Heft 1.

Hostert P., Kuemmerle T., Prishchepov A., Sieber A., Lambin E.F., Radeloff V.C., 2011. Rapid land use change after socio-economic disturbances: the collapse of the Soviet Union versus Chernobyl. Environmental Research Letters, vol. 6, no. 4, pp. 1-8.

Hryciuk G., Ruchniewicz M., SZAYnok B., ŻBiKowSKI A., 2008. Wysiedlenia, wypędzenia i ucieczki 1939-1959. Atlas ziem Polski. Warszawa: Demart.

JABŁOŃSKI Z., 1998. Ochrona dziedzictwa historycznego w krajobrazie a działalność samorzadów terytorialnych [in:] Z. Jabłoński, W. Tomaszewski (eds.), Ochrona wartości przyrodniczych i kulturowych - metodyka opracowań studialnych. Przegląd Regionalny, vol. 3, no. 1, pp. 33-42.

Khanal N.R., Watanabe T., 2006. Abandonment of agricultural land and its consequences. A case study in the Sikles Area, Gandaki Basin, Nepal Himalaya. Mountain Research and Development, vol. 26, no. 1, pp. 32-40.

KienAST F., 1993. Analysis of historic landscape patterns with GIS - a methodological outline. Landscape Ecology, vol. 8, no. 2, pp. 103-118.

KIsTOWsKI M., 2010. Eksterminacja krajobrazu Polski jako skutek wadliwej transformacji społeczno-gospodarczej państwa [in:] D. Chylińska, J. Łach (eds.), Studia krajobrazowe a ginące krajobrazy. Wrocław: Instytut Geografii i Rozwoju Regionalnego UWr, pp. 9-20.

KLÂštorna N., 2009. Akciâ-51. Kniga Pam'âtì. Brošnìv-Osada: Talâ.

KopCZYŃSKI K., 2009. Edukacyjne walory krajobrazu kulturowego [in:] S. Piechota (ed.), Turystyka a ochrona środowiska przyrodniczego - stan i perspektywy badań. Problemy Ekologii Krajobrazu, vol. 25, pp. 53-62.

KostrowICKI A.S., 1992. System „człowiek-środowisko" w świetle teorii ocen. Prace Geograficzne, 156, Warszawa: Instytut Geografii i Przestrzennego Zagospodarowania PAN.

KowAlczYK A., 1997. Odporność naturalna krajobrazów na różne typy przekształceń [in:] A. Richling, J. Lechnio, E. Malinowska (eds.), Zastosowania ekologii krajobrazu w ekorozwoju. Problemy Ekologii Krajobrazu, vol. 1, pp. 45-48.

KoZAK J., 2004. Wspótczesne zmiany powierzchni leśnej w górach świata. Przeglad Geograficzny, vol. 76, no. 3, pp. 307-326.

Kuemmerle T., Hostert P., Radeloff V.C., van der Linden S., Perzanowski K., Kruhlov I., 2008. Cross-border comparison of post-socialist farmland abandonment in the Carpathians. Ecosystems, vol. 11, pp. 614-628.

KULCZYK S., 2010. „Ginace krajobrazy” a turystyka - wzajemne korzyści czy konflikt? [in:] D. Chylińska, J. Łach (eds.), Studia krajobrazowe a ginqce krajobrazy. Wrocław: Instytut Geografii i Rozwoju Regionalnego UWr, pp. 43-49.

LACH J., 1984. Geomorfologiczne skutki antropopresji rolniczej w wybranych częściach Karpat i ich Przedgórza. Prace Monograficzne Wyższej Szkoły Pedagogicznej w Krakowie, 66, Kraków: Wydawnictwo Naukowe WSP.

Land Abandonment, Biodiversity and the CAP, 2005. DLG, Utrecht: Government Service for Land and Water Management of the Netherlands.

MacDonald D., Crabtree J.R., Wiesinger G., Dax T., Stamou T., Fleury P., Gutierrez LazplTA J., GiBON A., 2000. Agricultural abandonment in mountain areas of Europe: Environmental consequences and policy response. Journal of Environmental Management, vol. 59, pp. 47-69. 
MAJChrowsKa A., 2008. Systematyzacja krajobrazów w wybranych krajach europejskich [in:] J. Lechnio, S. Kulczyk, E. Malinowska, I. Szumacher (eds.), Klasyfikacja krajobrazu. Teoria i praktyka. Problemy Ekologii Krajobrazu, vol. 20, pp. 127-134.

MotyKa G., 1999. Tak było w Bieszczadach. Walki polsko-ukraińskie 1943-1948. Warszawa: Oficyna Wydawnicza Volumen.

MYCZKOWSKI Z., 1998. Krajobraz wyrazem tozsamości w wybranych obszarach chronionych w Polsce. Monografia, ser. Architektura, 242, Kraków: Politechnika Krakowska.

Myga-Piątek U., 2001. Spór o pojęcie krajobrazu w geografii i dziedzinach pokrewnych. Przegląd Geograficzny, vol. 73, no. 1-2, pp. 163-176.

Myga-PiateK U., 2005. Krajobraz kulturowy w badaniach geograficznych [in:] U. Myga-Piatek (ed.), Krajobraz kulturowy. Aspekty teoretyczne i metodologiczne. Prace Komisji Krajobrazu Kulturowego PTG, vol. 4, pp. 40-53.

Myga-PiąteK U., 2012. Krajobrazy kulturowe. Aspekty ewolucyjne i typologiczne. Katowice: Uniwersytet Śląski.

ORŁOWSKA E., 2005. Kulturowy aspekt badań geograficznych [in:] U. Myga-Piątek (ed.), Krajobraz kulturowy. Aspekty teoretyczne i metodologiczne. Prace Komisji Krajobrazu Kulturowego PTG, vol. 4, pp. 55-64.

OstaszeWSKA K., 2002. Geografia krajobrazu. Wybrane zagadnienia metodologiczne. Warszawa: Wydawnictwo Naukowe PWN.

PAPRZYCKA A., 2005. Kryteria typologii i oceny krajobrazu kulturowego [in:] A. Szponar, S. Horska-Schwarz (eds.), Struktura przestrzenno-funkcjonalna krajobrazu. Problemy Ekologii Krajobrazu, vol. 17, pp. 78-83.

Phillips A., 1998. The Nature of Cultural Landscapes - A Nature Conservation Perspective. Landscape Research, vol. 23, no. 1, pp. 21-38.

Pietrzak M., 2006. Krajobraz - między natura a kultura (czy istnieja krajobrazy kulturowe?) [in:] W. Wołoszyn (ed.), Krajobraz kulturowy - cechy, walory, ochrona. Problemy Ekologii Krajobrazu, vol. 18, pp. 115-117.

PLIT F., 2002. Elementy składowe krajobrazu kulturowego [in:] A.T. Jankowski, U. Myga-Piątek, G. Jankowski (eds.), Problemy ochrony i kształtowania krajobrazu Górnego Ślaska na tle doświadczeń z innych regionów Polski. Prace
Komisji Krajobrazu Kulturowego PTG, vol. 1, pp. 21-25.

PLIT F., 2011. Krajobraz kulturowy - czym jest? Warszawa: WGiSR UW.

PoŁomski K., 2010. Miejsce i przestrzeń. Krajobraz w doświadczeniu mieszkańców Bieszczadzkiego Parku Narodowego. Warszawa: Wyd. Naukowe Scholar.

Reger B., Otte A., Waldhardt R., 2007. Identifying patterns of land-cover change and their physical attributes in a marginal European landscape. Landscape and Urban Planning, vol. 81, no. 1-2, pp. 104-113.

Richling A., 2006. Czy istnieja krajobrazy naturalne i kulturowe? [in:] W. Wołoszyn (ed.), Krajobraz kulturowy - cechy, walory, ochrona. Problemy Ekologii Krajobrazu, vol. 18, pp. 119-122.

Richling A., Solon J., 2011. Ekologia krajobrazu. Warszawa: Wydawnictwo Naukowe PWN.

SAlWICKA B., 1978. Zmiany w zaludnieniu i użytkowaniu ziemi wsi górskich Masywu Śnieżnika w strefie granicy rolno-leśnej. Acta Universitatis Wratislaviensis, vol. 324, Prace Instytutu Geograficznego, ser. B, no. 2, pp. 71-87.

Schama S., 1996. Landscape and Memory. New York: A.A. Knopf.

Sluiter R., Jong S.M., 2007. Spatial patterns of Mediterranean land abandonment and related land cover transitions. Landscape Ecology, vol. 22, no. 4, pp. 559-576.

SOLON J., 2008. Typy krajobrazu kulturowego Polski [in:] J. Lechnio, S. Kulczyk, E. Malinowska, I. Szumacher (eds.), Klasyfikacja krajobrazu. Teoria i praktyka. Problemy Ekologii Krajobrazu, vol. 20, pp. 109-115.

StrIJKER D., 2005. Marginal lands in Europe - causes of decline. Basic and Applied Ecology, vol. 6, no. 2, pp. 99-106.

TOMASZEWSKI J., 1968. Zmiany ludnościowe w osiedlach sudeckich ze szczególnym uwzględnieniem powiatów Jelenia Góra i Bystrzyca Kłodzka. Problemy Zagospodarowania Ziem Górskich, vol. 6, pp. 163-192.

Trojan P., 1980. Homeostaza ekosystemów. Ossolineum.

UNHR, 2011. Protecting the human rights of internally displaced persons in natural disasters. Challenges in the Pacific. Suva: United Nations Human Rights. 
VIDAL DE LA BLACHE P., 1922. Principes de géographie humaine. Paris: Armand Colin.

VINCENZS., 1980.Z perspektywy podróży. Kraków: Wyd. Znak.

Vos W., Meekes H., 1999. Trends in European cultural landscape development: perspectives for a sustainable future. Landscape and Urban Planning, vol. 46, no. 1-3, pp. 3-14.

Witmer F.D.W., O'Loughuin J., 2011. Satellite data methods and application in the evaluation of war outcomes: Abandoned agricultural land in Bosnia-Herzegovina after the 1992-1995 conflict. Annals of the Association of American Geographers, vol. 99, no. 5, pp. 1033-1044.

WojCIECHOWSKI K.H., 1986. Problemy percepcji i oceny estetycznej krajobrazu. Rozprawy Habilitacyjne, 28, Lublin: UMCS.

WoJcIECHOWsKI K.H., 2001. Cechy krajobrazu kształtowane stylem życia [in:] U. Myga-Piqtek (ed.), Krajobraz kulturowy. Idee, problemy, wyzwania. Sosnowiec: WNoZ UŚ, Oddział Katowicki PTG, pp. 154-159.

WojcIECHOWSKI K.H., 2010. Wartości i walory krajobrazów przemijajacych i efemerycznych [in:] D. Chylińska, J. Łach (eds.), Studia krajobrazowe a ginace krajobrazy. Wrocław: Instytut Geografii i Rozwoju Regionalnego UWr, pp. 37-42.

Wojtanowicz J., 2002. Geneza i wiek krajobrazów kulturowych Europy [in:] A.T. Jankowski, U. Myga-Piątek, G. Jankowski (eds.), Problemy ochrony i kształtowania krajobrazu Górnego Śląska na tle doświadczeń z innych regionów Polski. Prace Komisji Krajobrazu Kulturowego PTG, vol. 1, pp. 13-20.
WOLSKI J., 2006. Współczesny obraz dawnych granic własnościowych i gospodarczych w Bieszczadach [in:] J. Plit (ed.), Granice w krajobrazach kulturowych. Prace Komisji Krajobrazu Kulturowego PTG, vol. 5, pp. 117-126.

Wolski J., 2007. Przekształcenia krajobrazu wiejskiego Bieszczadów Wysokich w ciagu ostatnich 150 lat. Prace Geograficzne, 214, Warszawa: Instytut Geografii i Przestrzennego Zagospodarowania PAN.

WOLSKI J., 2008. Trwałość śladów dawnej gospodarki rolnej na nieużytkowanych wspótcześnie stokach w Bieszczadach Wysokich. Roczniki Gleboznawcze, vol. 59, no. 3-4, pp. 290-297.

WoLSKI J., 2009a. Następstwa zaniku antropopresji na obszarach górskich - dyskusja zależności "proces a region” w ujęciu różnoskalowym. Przegląd Geograficzny, vol. 81, no. 1, pp. 47-73.

WolskI J., 2009b. Trwałość krajobrazu wiejskiego na przykładzie przekształceń zbiorowisk roślinnych bieszczadzkiej "krainy dolin” w ciagu ostatnich 150 lat. Chrońmy Przyrodę Ojczysta, vol. 65, no. 6, pp. 441-448.

ZAGOżDżon A., 1980. Regiony peryferyjne a zagadnienia peryferyjnych układów osadniczych. Wybrane zagadnienia teoretyczne i badawcze. Przegląd Geograficzny, vol. 52, no. 4, pp. 815-825.
(C) Jacek Wolski

(C) Geographia Polonica

(C) Institute of Geography and Spatial Organization

Polish Academy of Sciences - Warsaw • 2016
Article first received • January 2016

Article accepted • August 2016 
http://rcin.org.pl 